\title{
Isolation of bluetongue virus from midges of Culicoides Schultzei complex in West Bengal, India
}

\begin{abstract}
Although no outbreak of clinical bluetongue has been reported so far, large numbers of sero-positive animals are present in different agro-climatic zones of West Bengal, an eastern state of India. The environmental parameters are quite conducive for propagation of Culicoides sp. in the state of West Bengal. In order to identify the vector of BTV that is circulating in West Bengal state, attempts were made to isolate BTV from Culicoides midges identified as members of Culicoides schultzei complex that were collected from localities having good number of sero-positive animals. Non-engorged midges were pooled to prepare sample and BTV was isolated using embryonated chicken eggs, followed by BHK-21 cell culture. Confirmation of BTV was made by RNA-PAGE and RT-PCR. This communication describes for the first time the isolation of BTV from midges of Culicoides schultzei complex from the eastern Indian state West Bengal indicating that they may be one of the vectors responsible for circulating BTV in this region.
\end{abstract}

Keywords: bluetongue virus, Culicoides schultzei complex, midges, RNA-page, RT-PCR
Volume 4 Issue 3 - 2016

\author{
Siddhartha Narayan Joardar,' Arkendu \\ Halder,' Panchanan Parui, ${ }^{2}$ Vikas Kumar, ${ }^{2}$ \\ Dhriti Banerjee ${ }^{2}$ and Chandan Lodh' \\ 'Department of Veterinary Medicine, West Bengal University of \\ Animal and Fishery Sciences, India \\ ${ }^{2}$ Zoological Survey of India, India
}

\begin{abstract}
Correspondence: Siddhartha Narayan Joardar, Collaborating Centre (Eastern region), All India Network Programme on Bluetongue, Department of Veterinary Medicine, Ethics and Jurisprudence, West Bengal University of Animal and Fishery Sciences, 37, Kshudiram Bose Sarani, Post Office- Belgachia, Kolkata-700037, West Bengal, India, Tel +091 332390 1037, Fax +91 332557 1986, Email joardar69@gmail.com
\end{abstract}

Received: October 26, 2016 | Published: December 15, 2016

\section{Introduction}

Bluetongue (BT) is an arthropod-transmitted non-contagious viral disease of domestic and wild ruminants, caused by bluetongue virus (BTV) of the genus Orbivirus, and family Reoviridae. Twenty four distinct BTV serotypes have been recognized for decades, many of which is thought to be capable of causing BT in ruminants. However, two further BTV serotypes, BTV-25 (Toggenburg orbivirus, from Switzerland) ${ }^{1}$ and BTV-26 (from Kuwait) ${ }^{2}$ have recently been identified in goats and sheep, respectively. In India, the first report of the disease was from Maharashtra in 1963 that experienced an outbreak accompanied by severe economic losses in sheep. ${ }^{3}$ Since then southern and western states of India experienced several incidences and/or outbreaks of BT from time to time. However, eastern and northeastern part of India didn't experience any outbreak as such. Out of 27 serotypes distributed globally, ${ }^{4} 22$ serotypes have been reported from various parts of the country and 13 different serotypes (BTV1$4,6,9,10,12,16-18,21,23$ ) have been isolated so far. ${ }^{5}$ Most of the cases, these BTV serotypes were detected from endemic southern parts (states) of India.

India is a vast country with diverse geo-climatic zones. A large proportion of the country is tropical, with high to moderate rainfall, and a climate that is conducive for propagation of the Culicoides species vector. Though there are more than 1400 species of Culicoides worldwide, ${ }^{6,7}$ about 60 species have been reported to occur in India. ${ }^{8}$ The state of West Bengal (latitude $21^{0} 38^{\prime} \mathrm{N}$ to $27^{\circ} 10^{\prime} \mathrm{N}$, longitude $85^{\circ} 50^{\prime} \mathrm{E}$ to $89^{\circ} 50^{\prime} \mathrm{E}$ ) has been divided into six agro-climatic zones, viz. Hill, Tarai, Old alluvial, New Alluvial, Red laterite and Coastal saline. The environmental parameters, viz. rainfall, temperature and relative humidity being quite conducive for propagation of Culicoides sp. in West Bengal, ${ }^{9}$ these midges breed profusely during the monsoons (May to September). As per 18th Quinquennial Livestock Census (2007) of West Bengal, the state possesses population of 1.57 million sheep, 15.06million goat and 19.18million cattle. Although no outbreaks of clinical bluetongue disease have been reported so far in this state, large numbers of sero-positive animals (sheep- $57.66 \%$, goat- $66.95 \%$ and cattle- $52.00 \%$ ) are present in different agroclimatic zones of West Bengal. ${ }^{10}$ This led us to believe in circulation of bluetongue virus (BTV) amongst vectors and animals of the state. At this point, isolation of BTV from two suspected abattoir sheep of Kolkata Maidan pasture could be done ${ }^{11}$ and serotyped as- 15 and 21. In this context, in order to identify the vector of BTV that is circulating in West Bengal state, attempts were made to detect and isolate BTV from Culicoides midges, collected from localities having good number of sero-positive animals.

\section{Materials and methods}

\section{Collection and identification of midges}

Midges were collected in batches $(n=9)$ from Kamarhati region $\left(22^{\circ} 67^{\prime} \mathrm{N}, 88^{\circ} 37^{\prime} \mathrm{E}\right)$ of 24-parganas district of West Bengal state (Figure 1). The area was chosen on the basis of presence of high percent of sero-positive animals in the state. Midges were collected from large ruminant (cattle and buffalo) shed in the evening hours (5.30-7.30 pm) using traditional sweep net. The trapped insects were sorted under a microscope and identification steps were followed based on the morphological characteristics. ${ }^{12,13}$

\section{Isolation of bluetongue virus}

Each batch of non-engorged midges was pooled to prepare individual sample. Now the samples $(n=9)$ each numbering up to 150 midges were ground in pestle and mortar with sterilized sand. After grinding, $10 \mathrm{ml}$ of sterilized phosphate buffered saline (PBS, $\mathrm{pH}$ 7.2) was added into it and the cells were disrupted (at $\left.0^{\circ} \mathrm{C}\right)$ using ultrasonicator (Hielscher Ultrasonics GmBH, Germany) with a titanium probe, with the peak-to-peak wavelength of $8 \mu$ to $10 \mu$ with 40 cycles of one minute's duration, to release the virus. Intravenous inoculation of filtered aliquot $(100 \mu \mathrm{l})$ of the disrupted midge cell 
suspension into 10 to 12 day-old embryonated chicken eggs (ECE) was used to detect the presence of BTV. ${ }^{11}$ For each sample, four ECE were used as test whereas two as control (where PBS, pH 7.2 was used as inoculums). The ECE were incubated at $33.5^{\circ} \mathrm{C}$ for seven days. Embryos that died within seven days of inoculation showing subcutaneous haemorrhages were considered suspected. Embryos that died within 24hours of inoculation were not considered for subsequent processing. Three blind passages in embryonated eggs were carried out for all the samples. Selected embryonic tissues (viz. spleen, kidney, heart, liver, muscle) were collected and emulsified, using a sterilized pestle and mortar, with PBS having antibiotics $(100 \mathrm{IU} / \mathrm{ml}$ benzylpenicillin and $100 \mu \mathrm{g} / \mathrm{ml}$ streptomycin sulphate) to make a $10 \%$ $(\mathrm{w} / \mathrm{v})$ suspension. This suspension was clarified by centrifugation and inoculated on to baby hamster kidney (BHK-21) confluent cell monolayers in $25 \mathrm{~cm}^{2}$ tissue flask (Nunk) using Dulbecco's modified Eagle's medium (DMEM, Sigma, USA) supplemented with $10 \%$ fetal calf serum (Sigma, USA). Infected cells were observed under microscope for cytopathic effect (CPE) produced up to 72hours postinfection (PI) and harvested for next cycle of infection. The harvested cells were filtered and $200 \mu \mathrm{l}$ of inoculums were used to infect fresh monolayer. Thus three passages in BHK-21 cells were carried out for each case and observed for up to 72 hours post-infection (PI) for cytopathic effect (CPE).

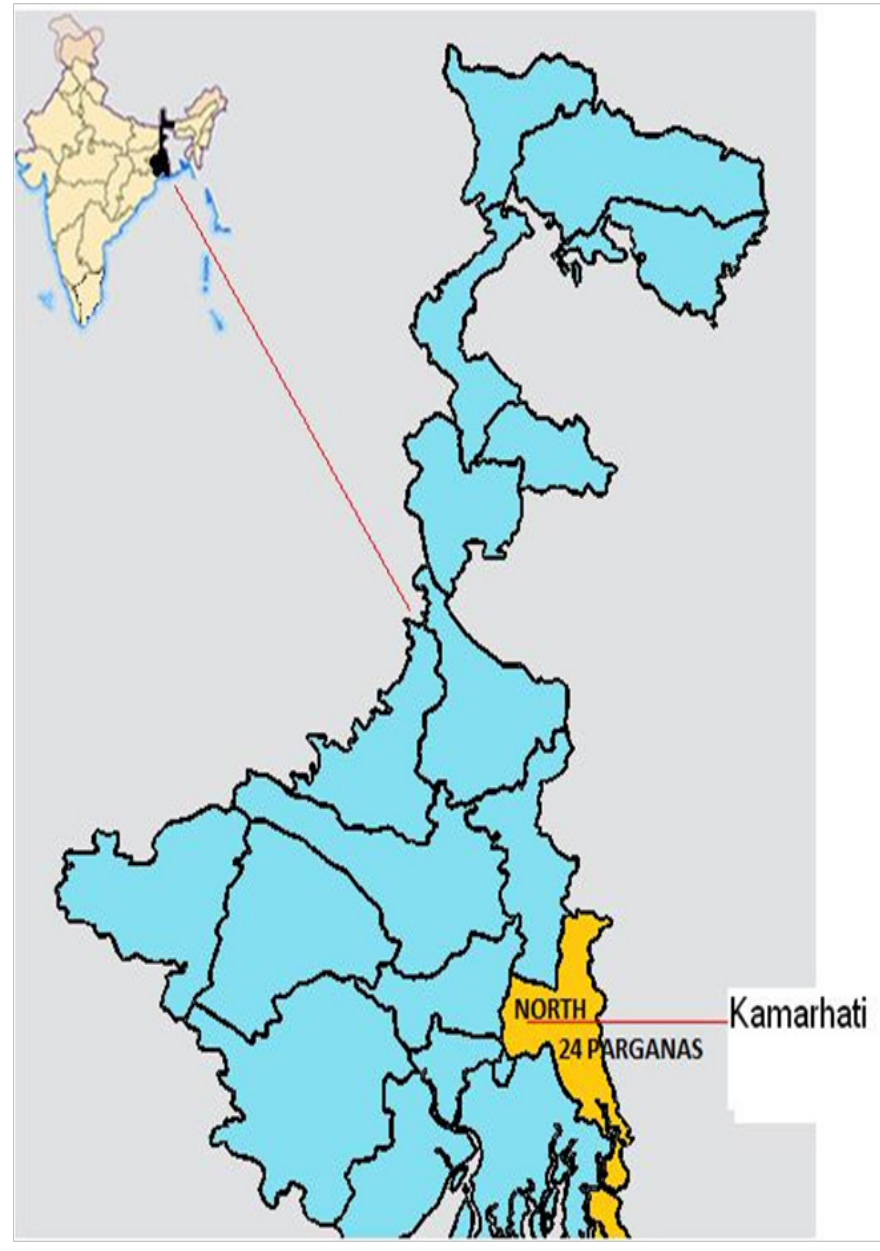

Figure I Collection area of midges. Kamarhati area is within 24 Parganas District of eastern Indian state West Bengal.

\section{RNA-PAGE}

Viral RNA was extracted from the BHK-21 cells using Trizol (Sigma, USA) ${ }^{14}$ and RNA-PAGE was performed as per Squire et al. ${ }^{15}$

\section{RT-PCR}

For further confirmation that the cell culture sample was positive for BTV, RT-PCR was performed using primers specific to the BTV NS1 gene (primer 1: 5'- GTTCTCTAGTTGGCAACCACC- 3', Primer 2: 5'- AAGCCAGACTGTTTCCCGAT- 3') ${ }^{16}$ to amplify part of the NS1 gene.

\section{Results}

\section{Identification of midges}

The midges collected and used in this study for virus isolation were identified as members of the Culicoides schultzei complex..$^{13,17,18}$ The midges (Figure 2) were medium sized flies with moderately hairy wings with numerous distinct pale spots including a pale spot over $\mathrm{r}-\mathrm{m}$ crossvein almost on the center of the vein. Radial cells were absent; anterior border of wing with two dark spots, one at the tip of radial vein forming the stigma, other at about the middle of cell R5. Aedaegus was prominent with saddle- shaped stem. Paramere was broad at the base, curved and tapered towards the tip with apical hairs.

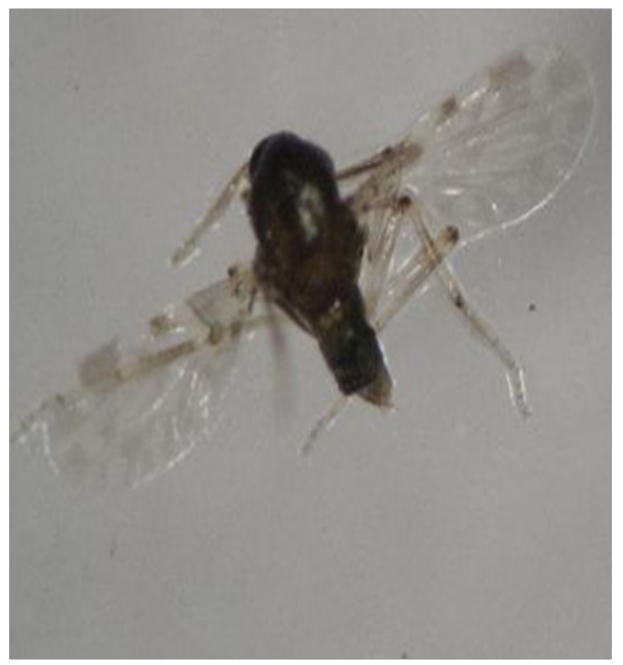

Figure 2 Midges of Culicoides schultzei complex under 40X.

\section{Isolation of BTV}

Embryos that died between 2 and 7days of inoculation in ECE showing subcutaneous haemorrhages were suspected of having BTV. When processed suspected samples $(n=3)$ were inoculated in BHK21 cell lines, one of the samples showed extensive CPE. Cellular destruction was evident as early as 24 hours, and the cells became enlarged, refractile and rounded. After 48hours PI there was foamy degeneration, cell aggregation and vacuolation inside the cells. CPE were seen throughout the monolayer by 72 hours PI, clumps of cells were detached from the flask and floated in the medium. This BHK-21 cell lysate sample (KH-1) was chosen for further processing.

\section{RNA-PAGE}

RNA-polyacrylamide gel electrophoresis showed 10-segmented RNA pattern (3:3:3:1) characteristic of BTV (result not shown). 


\section{RT-PCR}

The sample that gave CPE in BHK-21 cell culture and also showed the characteristic BTV- specific segmented RNA pattern was amplified by RT-PCR and confirmed positive for BTV (Figure 3) (Figure 4).

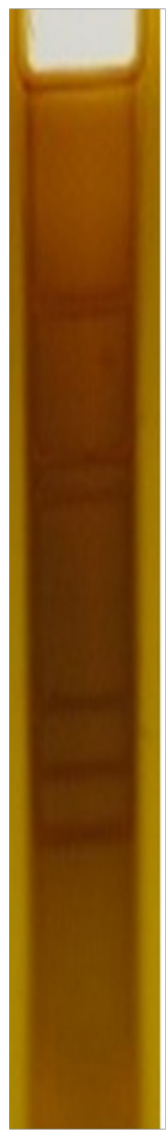

Figure 3 RT-PCR analysis of NSI gene of BTV in agarose gel.

A) DNA ladder

B) Sample (amplified product)

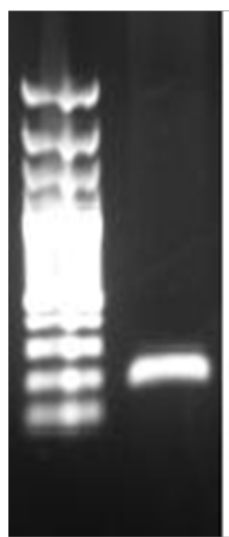

$274 \mathrm{bp}$

Figure 4 RT-PCR analysis.

\section{Discussion}

In the present study, midges were collected from localities (large ruminant shed) having good number of sero-positive animals and were identified based on morphological characteristics. In this study, midges were allocated to Culicoides schultzei complex. ${ }^{17}$ The most predominant midges of our collection happened to be the members of Culicoides schultzei complex like the other observations of recent past. Midges were trapped from different agro-climatic zones of West Bengal during the year 2009-2010 and members of C. schultzei complex were observed to be the most predominant species in all the agro-climatic zones. ${ }^{19,20}$ The Culicoides schultzei complex contain several species viz. C. Oxystoma, C. Schultzei, C. Subschultzei, C. Kingi, C. Rhizophorensis, C. Enderleini, C. Nevilli and $C$. Neoschultzei $i^{21,22}$ having very less morphological differences. Of these midges, C. Oxystoma and C. Schultzei were proven as potential vectors for bluetongue virus and epizootic haemorrhagic disease virus ${ }^{4,7}$ responsible for transmitting the virus among different groups of animals.

The species confirmation of Culicoides specimens in Schultzei complex needs serious taxonomic studies as high degree of variation in key characters make the accurate species identification challenging. ${ }^{23,24}$ This is especially true for Indian specimens. Hence, the authors advocate genomic analysis for proper species identification. Molecular identification based on DNA sequences can only resolved this impasse with perfection.

In the present investigation, virus (BTV) was isolated from batch samples of Culicoides midges using ECE and BHK-21 cell line and was confirmed by RNA-PAGE and subsequently by RT-PCR. Out of 9 batches (samples), one (KH-1) showed the presence of BTV in midges of Culicoides schultzei complex, the predominant species of eastern part of India. ${ }^{25}$ Non-engorged midges were used in the study to rule out the possibility that engorged midges might contain BTV from blood of infected animals and would act as mechanical vector. This means that midges of $C$. Schultzei complex act as one of the BTV vectors, at least, in the state of West Bengal. Other workers have reported the presence of BTV in various species of Culicoides from different countries. ${ }^{4,26-28}$ Earlier, BTV was isolated from pooled sample of Culicoides midges, collected from the western part of India. ${ }^{29,30}$

\section{Conclusion}

The present study identifies and confirms the presence of one of the vectors responsible for circulating virus (BTV) in this state (West Bengal) for the first time and hence, advocating preparedness to prevent menace of clinical BT in future, if any.

\section{Acknowledgements}

None.

\section{Conflict of interest}

Author declares that there is no conflict of interest.

\section{References}

1. Hoffman MA, Renzullo S, Planzer J, et al. Detection of oggenburg orbivirus by a segment 2-specific quantitative RT-PCR. Journal of Virological Methods. 2010;165(2):325-329.

2. Maan S, Maan NS, Nomikou K, et al. Complete genome characterization of a novel 26th bluetongue virus serotype from Kuwait. PLoS One. 2011;6(10):e26147.

3. Sapre SN. An outbreak of bluetongue in goats and sheep. Indian Veterinary Reviews. 2004;15:69-71. 
4. Chand K, Biswas, SK, Pandey AB, et al. Bluetongue in India: A review. Advances in Animal and Veterinary Sciences. 2014;3(11):605-612.

5. Zientara S, Sailleau C, Viarouge C, et al. Novel bluetongue virus in goats, Corsica, France. Emerging and Infectious Diseases. 2014;20:2123-2125.

6. Borkent A. The biting midges, the Ceratopogonidae (Diptera). In: Marquardt WH, editor. Biology of Disease Vectors. Burlington, Massachusetts: Elsevier Academic Press; 2005. p. 113-126.

7. Mellor PS, Osborne R, Jennings DM. Isolation of bluetongue and related viruses from Culicoides spp. in the Sudan. J Hyg (Lond). 1984;93(3):621-628.

8. Maheshwari G. Current Status of Bluetongue Disease, Its Vector and Pathogenesis in India. Proceedings of National Academy of Sciences, India. Sect B Biol Sci. 2012;82(4):463-475.

9. Biswas M, Joardar SN, Samanta I, et al. Conducive environment for propagation of potent bluetongue vector exists in West Bengal. Indian Journal Animal Health. 2011;50:46-48.

10. Panda MK, Mondal A, Joardar SN. Seroprevalence of bluetongue virus in sheep, goat and cattle in West Bengal, India. Animal Sci Reporter. 2011;5(3):105-110.

11. Joardar SN, Lodh C, Chakrabarti A, et al. Isolation of bluetongue virus serotypes 15 and 21 in West Bengal, India. Veterinary Record. 2009;165(25):751-752.

12. Sen P, Dasgupta SK. Studies on Indian Culicoides. Annals of Entomolical Society of America. 1959;52(5):617-643.

13. Dagupta SK. Morphotaxonomic features and species of Indian Culicoides. (Diptera: Ceratopogonidae). In: Prasad G, Srivastava RN, editors. Bluetongue: Indian Perspective. Hisar, India: HAU Press; 1995. p. $115-188$.

14. Chomczynski P, Sacchi N. Single-step method of RNA isolation by acid guanidium thiocyanate-phenol-chloroform extraction. Anal Biochem. 1987;162(1):156-159.

15. Squire KRE, Chuang RY, Osburn BI, et al. Rapid methods for comparing the double stranded RNA genomeprofiles of bluetongue virus. Vet Microbiol. 1983;8(6):543-553.

16. Bluetongue. Manual of Diagnostic Tests and Vaccines for Terrestrial Animals. OIE. 2004.

17. Wirth WW, Dyce AL. The current taxonomic status of the Culicoides vectors of bluetongue viruses. Prog Clin Biol Res. 1985;178:151-164.

18. Wirth WW, Hubert AA. The Culicoides of Southeast Asia (Diptera Ceratopogonidae). Memoirs in American Entomolical Institute. 1989;44:508-509.
19. Halder A. Isolation of Bluetongue Virus from Culicoides Schultzei. Vis$\dot{A}$-Vis Exploring the Role of Vector in Sub-Clinical Bluetongue Infection in Ruminants of West Bengal. M.V.Sc thesis submitted to West Bengal University of Animal and Fishery Science. 2011.

20. Panda MK. Prevalence of Bluetongue Disease in West Bengal with special emphasis on Development of user-friendly Diagnostic tool. M.V.Sc thesis submitted to West Bengal University of Animal and Fishery Science. 2010.

21. Boorman J. Culicoides (Diptera: Ceratopogonidae) of the Arabian peninsula with notes on their medical and veterinary importance. Fauna of Saudi Arabia. 1989;10:160-224.

22. Cornet M, Brunhes J. Revision des especes de Culicoides apparentees a C. schultzei (Enderlin, 1908) dans la region afrotropicale (Diptera, Ceratopogonidae). Bulletin de la Société entomologique de France. 1994;99:149-164.

23. Glick JI. Culicoides Biting Midges (Diptera: Ceratopogonidae) of Kenya. J Med Entomol. 1990;27(2):85-195.

24. Morag N, Saroya Y, Braverman Y, et al. Molecular Identification, Phylogenetic Status, and Geographic Distribution of Culicoides oxystoma (Diptera: Ceratopogonidae) in Israel. PLoS One. 2012;7(3):e33610.

25. Halder A, Joardar SN, Parui P, et al. Prevalence of Midges: Potent Vectors for Bluetongue Virus Infection in West Bengal, India. Advances in Veterinary and Animal Sciences. 2013;1(4S):45-60.

26. Caracappa S, Torina A, Guercio A, et al. Identification of a novel bluetongue virus vector species of Culicoides in Sicily. Vet Rec. 2003;153(3):71-74.

27. Braveman Y, Rubina M, Frish K. Pathogens of veterinary importance isolated from mosquitoes and biting midges in Israel. International Journal of Tropical Institute. 1981;2(3):157-161.

28. Savini G, Goffredo M, Monaco F, et al. Bluetongue virus isolations from midges belonging to the Obsoletus complex (Culicoides, Diptera: Ceratopogonidae) in Italy. Vet Rec. 2005;157(5):133-139.

29. Jain NC, Prasad G, Gupta Y, et al. Isolation of bluetongue virus from Culicoides species in India. Scientific and Technical Review of the Office International des Epizooties. 1988;7(2):375-378.

30. Dadawala AI, Biswas SK, Rehman W, et al. Isolation of bluetongue virus serotype 1 from Culicoides vector captured in livestock farms and sequence analysis of the viral genome segment-2. Transbound Emerg Dis. $2011 ; 59(4): 361-368$ 